\title{
Conscience, virtue, integrity and medical ethics
}

It is sometimes claimed that 'new fangled' philosophical medical ethics is unnecessary and indeed that it is positively disadvantageous, leading too often 'to abstract and inconclusive intellectual argument neither conducive to postprandial reflection nor necessarily relevant to the insistent demands on the busy practitioner throughout his day' (1). Particularly in medical education, as Osler so quaintly put it, 'What have bright eyes red blood quick breath and taut muscles to do with philosophy?'(2). Rather, clinicians so often claim, all that's needed for medical ethics is a sound conscience, good character, and integrity.

First, and vitally, it is important to affirm that few if any moral philosophers, let alone those who are specifically interested in medical ethics, would deny that sound conscience, good character and integrity are essential to moral life in general and medicomoral life in particular. But as soon as attempts are made to explain what is meant by these claims the need for some sort of critical philosophical analysis becomes apparent.

Conscience, for example, turns out to be an ambiguous concept. On the one hand is the concept of an unthinking but morally controlling force within us telling us what we should do and not do. This is the concept corresponding to the Oxford English Dictionary's 'internal conviction ... the faculty or principle which pronounces upon the moral quality of one's actions or motives, approving the right and condemning the wrong', and corresponding to Freud's account of the 'ego-ideal' or (later) 'superego' - the faculty of the mind in which the injunctions and prohibitions of 'father ... masters and others in authority . . . continues in the form of conscience to exercise the censorship of morals. The tension between the demands of conscience and the actual attainments of the ego is experienced as a sense of guilt'(3).

The second concept of conscience corresponds to the OED's 'inward knowledge . . . inmost thought . . . internal recognition of the moral quality of one's motives and actions'. It also corresponds to many analyses of conscience in the theological and philosophical literature in which conscience is an essentially rational faculty - in this journal for example D'Arcy wrote 'my conscience is simply myself, making reasoned judgements about moral questions' (4); and in their textbook on medical ethics Beauchamp an Childress say: 'In general, conscience is a mode of thought about one's acts and their rightness of wrongness, goodness or badness' (5).

Thus it is immediately clear that claims for the adequacy of a good conscience for medical ethics must make clear which of these two concepts of conscience is intended. If the former, non-thinking, non-rationat faculty of conscience is intended, the problem of conflict of conscience, whether intrapersonal of interpersonal, is left unamenable to reason; $\mathrm{Dr} A$ 's conscience tells him to transfuse the Jehovah's Witnes@ regardless of her own views, Dr B's conscience tells him not to transfuse such a patient. Where stabdso medical ethics? Which position is right and why? Is resolution or even attempt at resolution possibleôn desirable? Perhaps, it might be argued, attempts+a such resolution could be made by appealing to the other two members of the trio, good character an ${ }^{\circ}$ integrity. They are considered below, but it is difficule to deny the possibility, at least, that Drs A and B ar $\vec{E}$ both of good character and both people of integrity.

The obvious way out of such an impasse is to choose the other concept of conscience, in which the exercise. of reason is an essential element. But if that concept of conscience is chosen the original claim - that mora philosophy can be dispensed with, and medical ethic be allowed to rest on conscience, good character and integrity - becomes vacuous. For 'making reasone $\$$ judgements about moral questions' and 'thought abour one's acts and their rightness or wrongness, goodness or badness' are among the main constituents of the activity of moral philosophy.

Perhaps the concept of integrity can rescue the claim? Again there is a preliminary problem of ambiguity: integrity can mean some morally specifie and admirable condition such as 'sinlessness .. ب soundness of moral principle ... uprightnes honesty, sincerity' or 'the character of uncorrupte virtue'; alternatively and quite differently it can mean more literally, completeness or wholeness. (Dictionary definitions such as these are rarely if ever of an substantive value in philosophical discussion - but they are often exceedingly valuable for showing briefle and conclusively that one word does in fact have different meanings). The usual sense of integrity relie 
on in moral philosophy leans upon the latter more literal concept of (moral) wholeness - it is the concept of being one's own man or woman. It involves identifying oneself with a particular moral stance and sticking to it in adversity and in the face of other temptation to abandon it; it involves a sense of what one can and cannot live with and is thus a fundamental part of one's moral character and moral identity, one's moral wholeneness. But this sense of integrity - the sense roughly of being one's own person, of doing one's own moral thing - does not seem to obviate the need for moral criticism, reflection and argument any more than reliance on one's (unreflective) conscience does. For people notoriously vary as to what they morally speaking can and cannot live with; and if impasse or war is to be avoided some sort of rational reflection is required. Furthermore, how is one properly to decide what sort of moral agent one ought to be, where one must say 'enough, no further', without such reflection and criticism?

The philosopher Bernard Williams writes: 'one who displays integrity acts from those dispositions and motives which are most deeply his, and has also the virtues that enable him to do that' (6). Here we seem to have a concept of integrity which involves both the sense of wholeness and also some specific virtues akin to the second dictionary definition of integrity. Thus the discussion shifts to the third member of the triad, good character, which is equivalent to, and in our times a more common way of saying, virtuous character. Can reliance on good or virtuous character (in association with good conscience and integrity) be sufficient for medical ethics and obviate the need for philosophical medical ethics? There seem to be two senses in which an affirmative answer might be plausible. The first is the sense in which moral philosophy is claimed to be primarily concerned with the virtues and thus study of different sorts of moral philosophy - for instance study of deontological and utilitarian theories of ethics in the context of medical ethics - is claimed to be inappropriate. The second is the claim that doctors do not have to understand the philosophical underpinnings of their morality - they simply have to be good moral agents - doctors of good or virtuous character.

There is no doubt that virtue theories of ethics are making a comeback after having been for a long time out in the philosophical cold. Geach, Foot, Von Wright, Wiggins, McDowell and MacIntyre are prominent in this contemporary philosophical movement, which is largely oriented towards development of Aristotelian ethical theory, especially concerning the nature and logic of 'practical reasoning', the Aristotelian claim that ethics stems from man's telos or proper end which is eudaimonia or happiness in the sense of flourishing, and the claim that it is development and exercise of the virtues which constitute such flourishing. Despite the contrary arguments of MacIntyre (7) there seems no reason in principle why Aristotelian virtue theory should not be compatible with contemporary moral philosophy (8) of both deontological and utilitarian persuasion. Exemplars of both categories can certainly be construed to be fundamentally concerned with the good for man, and both are able to find room for the virtues, at least as means to that good, and often as partly constitutive of that good. Be that as it may, the important point in this context is that questions about the centrality or otherwise of the virtues are philosophical questions. Thus even if it were agreed that moral philosophy is primarily about the virtues it would be absurd to suggest that this made it possible for medical ethics to do without moral philosophy.

Unless of course the claim is that while someone may properly be concerned with critical study of the virtues, doctors need not be - they only need to be virtuous, ie of good character. Once again the problems of such a claim are unpacked along with the contents. What are the virtues of a good doctor (or the components of his good character)? This is a question recurrently discussed by medical educators and disagreement, as well as a wide variety of proposed answers, is characteristic of such discussions (9). The idea that this question is not a proper concern of the medical profession is hardly likely to appeal to the sorts of doctors who claim that doctors need not be concerned with the critical study of the virtues. Yet to answer it without such study - without critical philosophical study of the moral assumptions and objectives of medical practice - is somewhat like specifying the syllabus for therapeutics while claiming that neither the medical students nor the doctors laying down the syllabus need know any pharmacology. Of course such ignorance used of necessity to be the case in medical training, and we look back with some regret at those times. Shall we not equally look back with regret at our contemporary readiness voluntarily to eschew critical moral philosophy?

\section{References and notes}

(1) Watt J. Conscience and responsibility. British medical journal 1980; 281: 1687-1688.

(2) Osler W. A way of life. Springfield, Illinois: C C Thomas, 1969:3. The central theme of his talk to medical students, given in 1913, was that they should learn the habit of regular work and to live for each day.

(3) Freud S. The ego and the id and other works, 1923-1925. In: Strachey J, Freud A, Strachey A and Tyson A, eds. The standard edition of the works of Sigmund Freud. London: Hogarth Press and Institute of Psychoanalysis, vol 19: 49.

(4) D'Arcy E. Conscience. Fournal of medical ethics 1977; 3: 98-99.

(5) Beauchamp T L, Childress J F. Principles of biomedical ethics (2nd ed). New York and Oxford: Oxford University Press, 1983: 270. 
them, there is still the question which Dr Boughton raises of the procedures which it is expedient or even morally permissible to use to curb it (and similar activities). Dr Boughton notes that legislation can be counter-productive and that education is sometimes more effective. This is true, and one could add here that even were it the case that legislation might sometimes be effective there is still the question as to whether there can be too high a price to pay for the enforcement of principles which might in themselves be desirable expressions of liberalism. Switzerland is sometimes mentioned as a country in which the enforcement of morally desirable principles has produced an undesirable social atmosphere. The general point is that liberalism is not simply about what ought or ought not to be enforced but also, as $\mathrm{Dr}$ Boughton illustrates, about ways of proceeding to convince people by education and example (many doctors and nurses smoke and drink heavily) as to how they ought to behave towards others.

The conceptual question of what constitutes harm to others is brought out in a sharp way by one of $\mathrm{Dr}$ Boughton's main conclusions, that 'compulsory health and safety is a very dangerous notion which may only be justifiable when the public health interest, and not its economic interest is at stake'. But is it not true that a person or a State is harmed when resources which might otherwise be used on education, housing, the arts . . . are directed to finance the consequences of avoidable self-indulgence? An answer to this question turns on a philosophical analysis of the concept of harm, as we can see if we examine another tradition which has a different approach to 'harm' and 'compulsion' - collective socialism.

We tend to think of collective socialism in terms of the Soviet or Chinese varieties, but in fact there is a native English variety which goes back to the Levellers of the seventeenth century. Indeed, the origins of this form of socialism are to be found in Christianity, which tells us that we are 'members one of another'. Whereas the tradition of liberalism stresses freedom and the satisfaction of individual wants, the tradition of socialism stresses fraternity and the satisfaction of individual needs. It is this second tradition which led to the setting-up of the Welfare State. The idea behind the Welfare State is that a person's health, education, old age, and so on are too important to be left to the cutand-thrust of market competition or charity, and that the State should therefore provide a system more or less free to all but paid for by graduated taxation. The slogan here is: from each according to his ability, to each according to his need. It was assumed by the pioneers of the Welfare State that it could be grafted on to the liberal tradition and that economically and morally we could have the best of individualism and socialism. It is this assumption that creates the problem of the right to be unhealthy. The problem arises when, in terms of one tradition, we are sympathetic to the right to be unhealthy and, in terms of the other, we have a duty to care for the unhealth of others, where 'care for' means 'pay for through heavy taxation'.

Within the tradition of collective socialism the terms 'compulsion' and 'freedom' take on a different aspect. Firstly, the sharp distinction in liberalism between your self and its freedom and my self and its freedom is minimised; we are 'members one of another'. Secondly, the State is not something alien to the self and its essential freedom, but rather the laws of the State are an expression of the self; as Rousseau puts it, they force us to be free. (Again, there are Christian antecedents for this view - 'In Thy service is perfect freedom'.) What for the liberal is State 'compulsion' or 'sterile paternalism' constitutes for the socialist an expression of his true social self.

The theoretical confusions we can find ourselves in are due to the fact that we are almost as much influenced by the collectivist ideas of Christian socialism as we are by the idea of liberal individualism. Nor do I advocate any attempt to impose consistency in the practicalities of the moral and political sphere. It is preferable to take each issue as it comes - seat belts, fluoride, boxing . . . on a pragmatic basis. And if a preference for the muddle of piecemeal social engineering over the consistency and purity of political doctrine of the Right or the Left is still liberalism, then so be it.
(6) Williams B. Moral luck. Cambridge: Cambridge University Priess, 1981: 49.

(7) MacIntyre A. After virtue - a study in moral theory. London: Duckworth, 1981: 216.

(8) See reference (5) $265-268$, for an indication of how such compatibility can be construed.

(9) See for example Crisp A H. Selection of medical students - is intelligence enough? A discussion paper. Fournal of the Royal Society of Medicine 1984; 77: 35-39, and the authors he cites for advocacy of a wide range of medical virtues. For (a these days uncommon) advocacy of humility as a medical virtue see Pappworth M H. A primer of medicine. (3rd ed.). London: Butterworth, 1971: 31 and Linzer M. Doing what 'needs' to be done. New England Journal of Medicine 1984; 310: 469-470. For a brief non-medical account of the medical virtues see May W F in: Callahan D, Bok S, eds. Ethics teaching in higher education. Hastings on Hudson: Hastings Centre, 1980: 230-233. 